\title{
PERAMALAN PENJUALAN MINUMAN LOVE JUICE PRODUK PT. KALBE FARMA TBK. DI KOTA MATARAM
}

\section{FORECASTING SALES OF LOVE JUICE PRODUCED BY PT. KALBE FARMA TBK. IN MATARAM}

\author{
Oleh \\ Olivia Benedicta Karuna W., FX. Edy Fernandez, dan Taslim Sjah \\ Program Studi Agribisnis Fakultas Pertanian Unram
}

\begin{abstract}
ABSTRAK
Penelitian ini bertujuan untuk: (1) Menganalisis perkembangan penjualan minuman Love Juice yang dipasarkan oleh PT. Kalbe Farma Tbk. di Kota Mataram, (2) menganalisis metode peramalan yang tepat untuk meramalkan penjualan minuman Love Juice pada PT. Kalbe Farma Tbk. di Kota Mataram, (3) Meramalkan penjualan minuman Love Juice tahun 2019 pada PT. Kalbe Farma Tbk. di Kota Mataram. Penelitian ini dilaksanakan di PT. Kalbe Farma Tbk.

Penelitian ini menggunakan metode deskriptif dengan unit analisis berupa produk minuman Love Juice oleh PT. Kalbe Farma Tbk. Cabang Kota Mataram dengan empat varian rasa, yaitu jambu biji, delima, jeruk, dan mangga. Penentuan daerah sampel ditentukan menggunakan purposive sampling dengan objek penelitian di PT. Kalbe Farma Tbk. Cabang Kota Mataram. Jenis penelitian ini menggunakan data kuantitatif, dengan sumber data yaitu data sekunder.

Hasil penelitian menunjukkan: (1) Penjualan minuman Love Juice selama 5 tahun terakhir bersifat fluktuatif; (2) Metode peramalan yang tepat digunakan untuk meramalkan penjualan minuman Love Juice adalah metode Trend Least Square; (3) Peramalan penjualan minuman Love Juice rata-rata perbulan yaitu rasa jambu biji sebanyak 4.205 .645 botol, rasa delima sebanyak 3.784.224 botol, rasa jeruk sebanyak 2.345 .674 botol, dan rasa mangga sebanyak 6.667.340 botol.
\end{abstract}

Kata Kunci : Peramalan, Penjualan, Love Juice 


\begin{abstract}
The research was purposed to: (1) Analyze the development of sales of Love Juice drinks marketed by PT. Kalbe Farma Tbk. in the city of Mataram, (2) analyzing the right forecasting method to forecast the sale of Love Juice drinks at PT. Kalbe Farma Tbk. in Mataram City, (3) Forecasting the sale of Love Juice drinks in 2019 at PT. Kalbe Farma Tbk. in the city of Mataram. This research was conducted at PT. Kalbe Farma Tbk.

This study uses a descriptive method with an analysis unit in the form of Love Juice drinks by PT. Kalbe Farma Tbk. Mataram City Branch with four variants, namely guava, pomegranate, orange, and mango. Determination of sample area was determined using purposive sampling with the object of research at PT. Kalbe Farma Tbk. Mataram City Branch. This type of research uses quantitative data, with data sources, namely secondary data.

The results of the study show: (1) Sales of Love Juice drinks during the last 5 years are volatile; (2) The correct forecasting method used to forecast sales of Love Juice drinks is the Trend Least Square method; (3) Forecasting sales of Love Juice drinks on average per month, namely guava flavor $4,205,645$ bottles, pomegranate flavor 3,784,224 bottles, orange flavor 2,345,674 bottles, and mango flavor 6,667,340 bottles.
\end{abstract}

\title{
Keywords : Forecasting, Sales, Love Juice
}

\section{PENDAHULUAN}

Agroindustri merupakan bagian (subsistem) agribisnis yang memproses dan mentraformasikan bahan-bahan hasil pertanian menjadi barang-barang setengah jadi atau barang jadi yang langsung dapat dikonsumsi, ataupun menjadi barang/bahan hasil produksi industri yang digunakan dalam proses produksi (Udayana, 2011). PT. Kalbe Farma merupakan salah satu perusahaan yang bergerak dalam bidang pengolahan dan pemasaran agroindustri. Beberapa jenis produk yang diproduksi dan dipasarkan antara lain makanan dan minuman, obat-obatan, suplemen dan vitamin, kecantikan, serta susu dan makanan bagi ibu dan bayi. Salah satu jenis minuman yang diproduksi adalah minuman sari buah Love Juice. Minuman tersebut terbuat dari bahan utama sari buah asli yang diproses lebih lanjut untuk dapat dikonsumsi oleh konsumen (Kalbe Farma, 2019).

Banyaknya produk-produk minuman sari buah yang sejenis di pasaran, membuat penjualan produk minuman Love Juice terkadang mengalami penaikan penjualan atau penurunan penjualan atau fluktuatif. Salah satu 
strategi penjualan dan untuk menunjang operasional yang dapat dilakukan adalah dengan melakukan peramalan penjualan produk yang akurat, sehingga kebutuhan pasar dapat terpenuhi dan mendatangkan laba bagi perusahaan. Penelitian ini bertujuan (1) Menganalisis perkembangan penjualan minuman Love Juice yang dipasarkan oleh PT. Kalbe Farma Tbk. di Kota Mataram, (2) menganalisis metode peramalan yang tepat untuk meramalkan penjualan minuman Love Juice pada PT. Kalbe Farma Tbk. di Kota Mataram, (3) Meramalkan penjualan minuman Love Juice tahun 2019 pada PT. Kalbe Farma Tbk. di Kota Mataram.

\section{METODOLOGI PENELITIAN}

Metode yang digunakan dalam penelitian ini adalah metode deskriptif dengan unit analisis berupa produk minuman Love Juice oleh PT. Kalbe Farma Tbk. Cabang Kota Mataram dengan empat varian rasa, yaitu jambu biji, delima, jeruk, dan mangga. Penentuan daerah sampel ditentukan menggunakan purposive sampling dengan objek penelitian di PT. Kalbe Farma Tbk. Cabang Kota Mataram. Jenis penelitian ini menggunakan data kuantitatif, dengan sumber data yaitu data sekunder. Untuk menghitung nilai peramalan penjualan tahun 2019 digunakan tiga perbandingan metode, yaitu Single Moving Average, Double Exponential Smoothing, dan Trend Least Square.

Single Moving Average menggunakan rumus (Firdaus, 2006): $\mathrm{F}_{\mathrm{t}-1}=\left(\mathrm{X}_{\mathrm{t}}+\mathrm{X}_{\mathrm{t}-1}+\mathrm{X}_{\mathrm{t}-}\right.$ $\left.2 \ldots .+X_{t-n+1}\right) / n$, Dimana : $F_{t+1}=$ ramalan untuk periode $k e{ }_{t+1}, X_{t}=$ data periode ke $\mathrm{t}, \mathrm{n}=$ jumlah waktu rata-rata bergerak.

Double Exponential Smoothing menggunakan rumus (Firdaus, 2006): $\left(\mathrm{F}_{\mathrm{t}+\mathrm{m}}\right)=$ $a_{t}+b_{t}(m)$, dengan perolehan nilai : $a_{t}=2 S_{t}^{\prime}-S^{\prime \prime}{ }_{t} ; b_{t}=\alpha /(1-\alpha)\left(S^{\prime} t-S^{\prime \prime} t\right) ; S_{t}^{\prime}$ $=\alpha X_{t}+(1-\alpha) S_{t-1}^{\prime} ; \quad S^{\prime \prime}{ }_{t}=\alpha S_{t}^{\prime}+(1-\alpha) S^{\prime \prime}{ }_{t-1}$, Dimana : $F_{(t+m)=\text { ramalan untuk }}$ waktu periode ke $\mathrm{t}+\mathrm{m}, \mathrm{a}_{\mathrm{t}}=$ konstanta, $\mathrm{b}_{\mathrm{t}}=$ slope, $\mathrm{m}=$ jangka waktu peramalan, $S^{\prime} t=$ pemulusan pertama periode- $t, S^{\prime \prime} t=$ pemulusan kedua periode- $t, X_{t}=$ nilai penjualan.

Trend Least Square menggunakan rumus (Firdaus, 2006) : $\mathrm{Y}=\mathrm{a}+\mathrm{bX}$, dengan perolehan nilai : $a=\sum Y / n ; b=\sum X Y / \Sigma X^{2}$, Dimana : $Y=$ variabel yang akan diprediksi, $\mathrm{a}=$ konstanta, $\mathrm{b}=$ kemiringan garis regresi, $\mathrm{x}=$ variabel bebas (waktu).

Untuk mengetahui ketepatan metode peramalan menggunakan nilai Mean Absolute Deviation (MAD).

MAD menggunakan rumus (Nasution, 2003) : MAQ $=\Sigma\left(X_{t}+F_{t}\right) / n$, dimana : $\mathrm{MAD}=$ Mean Absolute Deviation, $\mathrm{X}_{\mathrm{t}}=$ data historis periode- $\mathrm{t}, \mathrm{F}_{\mathrm{t}}=$ data ramalan periode-t, $\mathrm{n}=$ jumlah periode ramalan. 


\section{HASIL DAN PEMBAHASAN}

Minuman Love Juice yang dianalisis pada penelitian ini hanya pada ukuran $300 \mathrm{ml}$ pada keempat varian rasa, yaitu jambu biji, delima, jeruk, dan mangga. Penjualan minuman Love Juice selama 5 tahun terakhir, sejak Januari 2014 sampai dengan Desember 2018 menunjukkan pergerakan naik dan turun atau fluktuasi pada ke empat varian rasa, yaitu jambu biji, jeruk, delima, dan mangga. Berdasarkan data penjualan minuman Love Juice pada PT. Kalbe Farma Tbk. diketahui penjualan perbulan tertinggi untuk rasa jambu biji sebanyak 9.737.200 botol pada bulan Juni 2016, rasa jeruk sebanyak 5.442 .800 botol pada bulan Mei 2015, untuk rasa delima yaitu sebanyak 15.004.000 botol di bulan Juni 2017, serta pada mangga sebanyak 11.255.200 botol di bulan September 2018. Penjualan perbulan terendah terjadi pada waktu yang berbeda diantara keempat varian rasa, yaitu antara lain pada Love Juice jambu biji tingkat penjualan terendah pada bulan Maret 2014 yaitu sebanyak 1.188 .000 botol, pada Love Juice delima terjadi pada bulan November 2018 yaitu sebanyak 792.000 botol, pada Love Juice mangga sebanyak 831.600 botol pada tahun bulan Mei 2016, serta pada Love Juice jeruk bulan November 2017 sebanyak 580.800 botol. jambu biji memiliki rata-rata penjualan perbulan sebesar 4.067 .433 botol selama 5 tahun terakhir, rasadelima memiliki rata-rata penjualan perbulan sebesar 3.599 .997 botol dan rasa jeruk dengan rata-rata penjualan perbulan sebesar 2.660 .093 botol selama 5 tahun terakhir. Untuk 3 tahun terakhir pada rasa mangga memiliki rata-rata penjualan perbulan sebesar 4.057 .517 botol. Sedangkan rata-rata penjualan pertahun untuk rasa jambu biji, delima, jeruk dan mangga secara berturut-turut sebesar 48.809 .200 botol, 43.199 .960 botol, 31.921 .120 botol, dan 48.690 .200 botol.

Metode peramalan kuantitatif terbaik untuk meramalkan penjualan minuman Love Juice pada PT. Kalbe Farma Tbk. di Kota Mataram ditentukan dengan melihat pola data penjualan 5 tahun terakhir, yaitu tahun 2014-2018 yang terbentuk.

Penjualan minuman Love Juice memiliki pola musiman pada keempat varian rasanya, yaitu jambu biji, delima, jeruk dan mangga.. Pada pola data penjualan minuman Love Juice delima terdapat pola horizontal. Plot data yang menunjukkan pola trend juga dapat dilihat pada hasil grafik penjualan minuman Love Juice mangga. Pola trend yang terbentuk cenderung meningkat dari tiap periode ke periode. Berdasarkan analisis pola data tersebut, maka metode peramalan time series yang sesuai dengan pola data penjualan antara lain metode rata-rata bergerak tunggal (Single Moving Average), metode pemulusan eksponensial ganda (Double Exponential 
Smoothing), dan metode Trend Least Square. Ketiga metode tersebut lalu dihitung perolehan nilai kesalahan terkecil melalui nilai MAD (Mean Absolute Deviation). Metode peramalan yang memiliki nilai MAD terkecil merupakan metode peramalan yang paling tepat digunakan untuk peramalan penjualan di tahun mendatang.

Gambar 1. Pola Data Penjualan Minuman Love Juice, 2014-2018

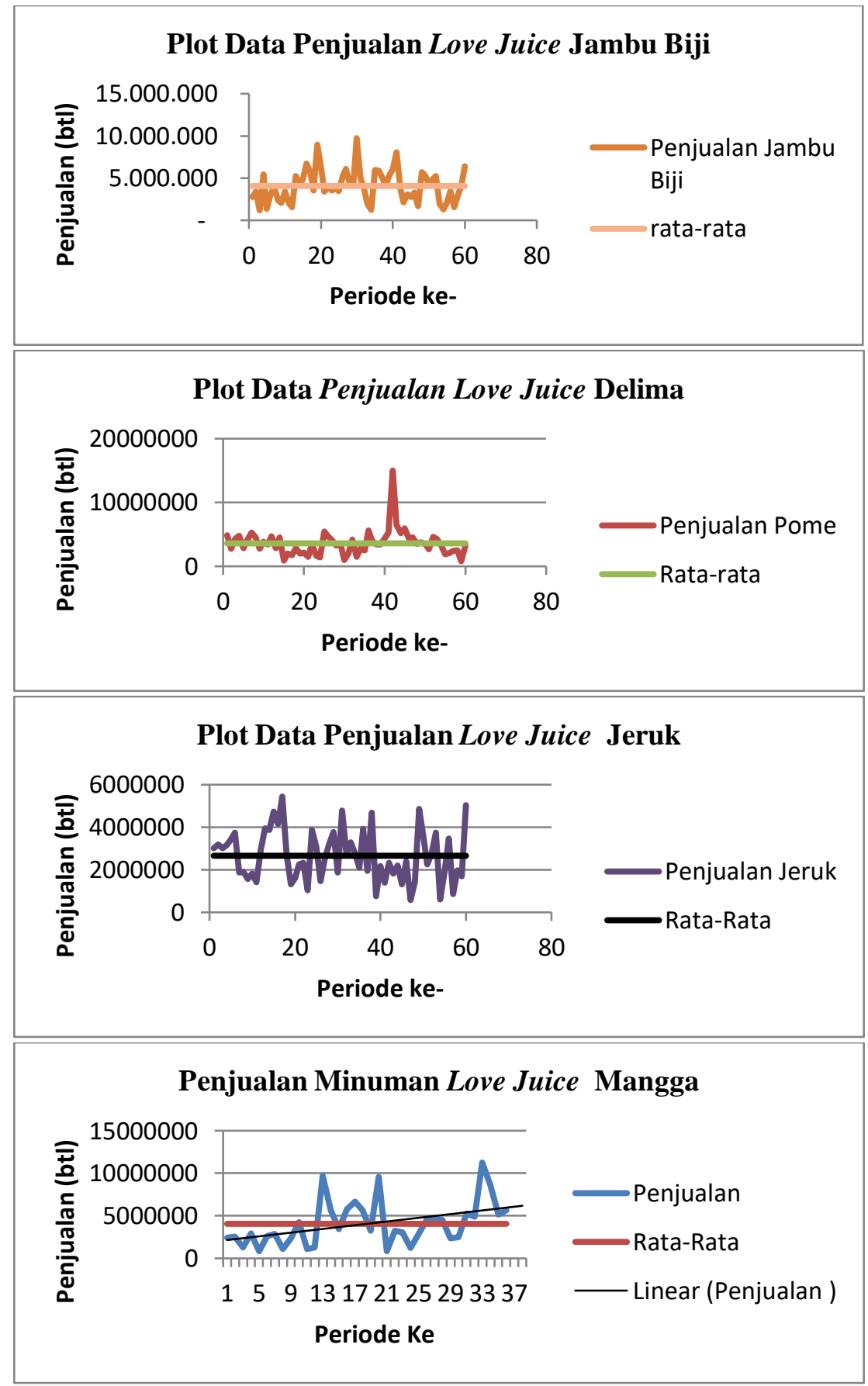

Sumber :Data Sekunder Diolah (2019) 
Tabel 1. Perbandingan Nilai MAD dengan Metode Peramalan Single Moving Average

\begin{tabular}{lccc}
\hline \multirow{1}{*}{ Varian } & \multicolumn{3}{c}{ MAD } \\
\cline { 2 - 4 } (Triwulan) & $\begin{array}{c}\text { Ordo 6 (Setengah } \\
\text { Tahun) }\end{array}$ & $\begin{array}{c}\text { Ordo 12 } \\
\text { (Tahunan) }\end{array}$ \\
\hline Jambu biji & $1.633 .763,74$ & $1.730 .775,31$ & $1.579 .867,36$ \\
Delima & $1.315 .508,77$ & $1.326 .571,60$ & $1.566 .765,28$ \\
Jeruk & $1.077 .665,50$ & $1.185 .922,22$ & $1.106 .409,03$ \\
Mangga & $2.018 .052,53$ & $2.067 .868,89$ & $2.429 .870,83$ \\
\hline
\end{tabular}

Sumber : Data Sekunder Diolah (2019)

Pada metode Single Moving Average diketahui bahwa bahwa pada minuman Love Juice jambu biji memiliki nilai MAD terkecil pada ordo 12 atau tahunan, yaitu sebesar 1.579.867,36; pada Love Juice delima memiliki nilai MAD terkecil atau terjadi penyimpangan terkecil pada ordo 3 atau triwulan yaitu sebesar 1.315.508,77; pada Love Juice jeruk juga memiliki nilai MAD terkecil pada ordo 3 atau triwulan sebesar 1.077.665,50; pada Love Juice mangga nilai MAD terkecil di ordo 3 atau triwulan terdapat pula yaitu sebesar 2.018.052,53.

Tabel 2. Nilai MAD dengan Metode Double Exponential Smoothing

\begin{tabular}{l|c}
\hline \multicolumn{1}{c|}{ Varian Rasa } & Nilai MAD \\
\hline Jambu Biji & $1.542 .937,09$ \\
Delima & $1.349 .098,05$ \\
Jeruk & $1.012 .711,22$ \\
Mangga & $1.807 .129,32$ \\
\hline
\end{tabular}

Sumber : Data Sekunder Diolah (2019)

Pada metode Double Exponential Smoothing menghasilkan tingkat kesalahan yang diperoleh dari nilai MAD sebesar 1.542.937,09 untuk peramalan selama 5 tahun terakhir. Artinya penyimpangan dengan metode ini sebesar 1.542.937,09. Sedangkan Love Juice delima memiliki tingkat kesalahan dari nilai MAD atau nilai penyimpangan sebesar 1.349.098,05 dengan data aktual selama 5 tahun terakhir. Pada Love Juice jeruk memiliki nilai MAD sebesar $1.012 .711,22$. Artinya penyimpangan dengan metode ini sebesar 1.012.711,22. Pada rasa terakhir, yaitu Love Juice mangga memiliki deret waktu selama 36 bulan atau 3 tahun menghasilkan tingkat kesalahan dari nilai MAD sebesar 1.807.129,32. Hal tersebut menjelaskan bahwa terdapat penyimpangan dengan metode ini sebesar 1.807.129,32. 
Tabel 3. Hasil Perolehan Nilai MAD dalam Meramalkan Penjualan Love Juice dengan Metode Trend Least Square

\begin{tabular}{l|c}
\multicolumn{1}{c|}{ Varian Rasa } & MAD \\
\hline Jambu Biji & $1.485 .519,09$ \\
Delima & $1.305 .797,85$ \\
Jeruk & $945.067,87$ \\
Mangga & $1.710 .507,14$ \\
\hline
\end{tabular}

Sumber : Data Sekunder Diolah (2019)

Pada metode Trend Least Square varian yang memperoleh nilai MAD terkecil adalah pada Love Juice jeruk yaitu sebesar 945.067,87. Nilai MAD terkecil selanjutnya pada metode ini terdapat pada Love Juice delima dengan nilai MAD sebesar 1.305.797,85. Selanjutnya, terdapat Love Juice jambu biji tingkat kesalahan dari nilai MAD sebesar 1.485.519,09. Pada rasa terakhir, yaitu Love Juice mangga diperoleh nilai MAD sebesar 1.710.507,14.

Tabel 4. Nilai MAD yang Diperoleh dari Masing-Masing Metode Peramalan Pada Penjualan Minuman Love Juice di Kota Mataram

\begin{tabular}{lcccc}
\hline \multirow{2}{*}{ Metode Peramalan } & \multicolumn{4}{c}{ Varian } \\
\cline { 2 - 5 } & Jambu Biji & Delima & Jeruk & Mangga \\
\hline Single Moving & & & & \\
Average & $1.579 .867,36$ & $1.315 .508,77$ & $1.077 .665,50$ & $2.018 .052,53$ \\
Double Exponential & & & & \\
Smoothing & $1.542 .937,09$ & $1.349 .098,05$ & $1.012 .711,22$ & $1.807 .129,32$ \\
Least Square & $1.485 .519,09$ & $1.305 .797,85$ & $945.067,87$ & $1.710 .507,14$ \\
\hline
\end{tabular}

Sumber : Data Sekunder Diolah (2019)

Dari ketiga metode peramalan yang digunakan, terlihat pada Tabel 04 bahwa metode peramalan Trend Least Square merupakan metode peramalan terbaik yang dapat digunakan untuk meramalkan penjualan minuman Love Juice tahun 2019 pada PT. Kalbe Farma Tbk. Cabang Kota Mataram. Hal tersebut karena nilai MAD pada metode Trend Least Square paling kecil dibandingkan dengan metode Single Moving Average dan Double Exponential Smoothing.

Hasil perhitungan peramalan penjualan minuman Love Juice tahun 2019 di Kota Mataram disajikan pada Tabel 05. Rata-rata penjualan perbulan pada minuman Love Juice jambu biji, delima, jeruk, dan mangga secara berturut-turut yaitu 4.205 .645 botol, 3.784.224 botol, 2.245.674 botol, dan 6.667.340 botol. 
Tabel 5. Peramalan Penjualan Minuman Love Juice Periode Januari 2019Desember 2019 di Kota Mataram dengan Menggunakan Metode Trend Least Square

\begin{tabular}{lccc}
\hline \multicolumn{1}{c}{ Varian } & Bulan & Periode & Penjualan (botol) \\
\hline Jambu Biji & Januari & 61 & 4.184 .529 \\
& Desember & 83 & 4.226 .761 \\
& Per bulan & & 4.205 .645 \\
\hline Delima & Januari & 61 & 3.756 .078 \\
& Desember & 83 & 3.812 .369 \\
& Per bulan & & 3.784 .224 \\
\hline Jeruk & Januari & 61 & 2.308 .988 \\
& Desember & 83 & 2.182 .360 \\
& Per bulan & & 2.245 .674 \\
\hline Varian & Bulan & Periode & Penjualan (botol) \\
\hline Mangga & Januari & 37 & 6.069 .255 \\
& Desember & 59 & 7.265 .424 \\
& Per bulan & & 6.667 .340 \\
\hline
\end{tabular}

Sumber : Data Diolah Sekunder (2019)

Melalui peramalan penjualan tahun 2019, perusahaan memiliki acuan atau gambaran besaran persediaan (stock) Love juice pada masing-masing rasa sebagai perencanaan antisipasi besarnya permintaan pada tahun 2019. Kegiatan yang dapat mengoptimalisasikan penjualan tersebut dapat melalui perluasan pasar pada tempat yang belum menjual produk tersebut, seperti kantin sekolah, kantin rumah sakit, dan tempat-tempat wisata. Selain perluasan pasar, menjaga kualitas produk tetap baik hingga sampai ke tangan konsumen merupakan salah satu hal yang penting untuk dilakukan. Penjualan melalui internet marketing salah bentuk strategi yang dapat dilakukan, seperti diketahui bahwa konsumen saat ini lebih aktif di media sosial. Melalui media sosial, perusahaan dapat memasarkan produk lebih baik lagi melalui promopromo atau iklan yang ditawarkan sehingga dapat menarik minat konsumen lebih banyak. Menjaga kesetiaan pelanggan termasuk dalam kegiatan pemasaran yang baik. Menjaga kesetiaan pelanggan dapat dilakukan dengan menawarkan promo-promo menarik, menciptakan sebuah hubungan yang menguntungkan, serta memberikan keuntungan bagi pelanggan yang setia. 


\section{KESIMPULAN DAN SARAN}

Berdasarkan hasil pembahasan tersebut, maka dapat ditarik kesimpulan sebagai berikut : (1) Penjualan minuman Love Juice ukuran 300 $\mathrm{ml}$ pada keempat varian rasa bersifat fluktuatif selama 5 tahun terakhir. Penjualan perbulan untuk rasa jambu biji terendah sebesar 1.188 .000 botol dan tertinggi sebesar 9.737 .000 botol dengan rata-rata perbulan sejumlah 4.067.433 botol; untuk rasa delima penjualan perbulan terendah sebesar 792.000 botol dan tertinggi sebesar 11.004 .000 botol dengan rata-rata perbulan sebesar 3.599.997 botol; pada rasa jeruk penjualan perbulan terendah sebesar 580.800 botol dan tertinggi sebesar 5.442 .800 botol dengan rata-rata perbulan sebesar 2.660 .093 botol;dan pada rasa mangga penjualan perbulan terendah sebesar 831.600 botol dan tertinggi sebesar 11.255.200 botol dengan rata-rata penjualan perbulan sebesar 4.057 .517 botol. (2) Metode peramalan terbaik yang dapat digunakan untuk meramalkan penjualan minuman Love Juice di Kota Mataram Tahun 2019 adalah metode Trend Least Square,dengan nilai Mean Absolute Deviation (MAD) pada rasa jambu biji, delima, jambu dan mangga secara berturut-turut sebesar 1.485.519,09; 1.305.797,85; 945.067,87; dan 1.710.507,14lebih kecil dibandingkan dengan Single Moving Average (SMA )dan Double Exponential Smoothing (DES). (3) Penjualan minuman Love Juice di Kota Mataram Tahun 2019 yang diramalkan dengan metode Trend Least Square pada rasa jambu biji yaitu diperoleh rata-rata penjualan perbulan sebanyak 4.205 .645 botol, pada rasa delima diramalkan rata-rata penjualan perbulan sebanyak 3.784.224 botol, pada rasa jeruk diramalkan rata-rata penjualan perbulan sebanyak 2.345.674 botol, serta pada rasa mangga diramalkan rata-rata penjualan perbulan sebanyak 6.667 .340 botol.

Berdasarkan hasil penelitian yang telah dilakukan di PT. Kalbe Farma Tbk. Cabang Kota Mataram, maka dapat disarankan bahwa : (1) PT. Kalbe Farma Tbk. Cabang Kota Mataram sebaiknya meningkatkan penjualan produk minuman Love Juice dengan beberapa cara, yaitu perluasan pasar, meningkatkan kualitas produk, penjualan melalui media social, serta menjaga kesetiaan pelanggan. (2) PT. Kalbe Farma Tbk. sebaiknya menerapkan metode peramalanTrend Least Square untuk meramalkan tingkat penjualan minuman Love Juice pada periode yang akan datang. Metode tersebut dapat dijadikan acuan untuk perencanaan persediaan produksi untuk mencegah terjadinya kelebihan produksi yang dapat merugikan perusahaan. 


\section{DAFTAR PUSTAKA}

Firdaus, M. 2006. Analisis Deret Waktu Satu Ragam. IPB Press. Jakarta.

Kalbe Farma. 2019. Tentang Kalbe. http://www.kalbe.co.id.[5 Januari 2019]

Nasution, A.H. 2003. Manajemen Industri. Penerbit Andi. Yogyakarta.

Udayana, I.G. B. 2011. Peran Agroindustri dalam Pembangunan Pertanian. 44: 4. 